\title{
"I live a hope despite my knowing better": James Baldwin in Conversation with Fritz J. Raddatz (1978)
}

\author{
Gianna Zocco University of Vienna
}

\begin{abstract}
This is the first English-language publication of an interview with James Baldwin conducted by the German writer, editor, and journalist Fritz J. Raddatz in 1978 at Baldwin's house in St. Paul-de-Vence. In the same year, it was published in German in the weekly newspaper Die Zeit, as well as in a book of Raddatz's conversations with international writers, and-in Italian translation-in the newspaper $\mathrm{La}$ Repubblica. The interview covers various topics characteristic of Baldwin's interests at the time-among them his thoughts about Jimmy Carter's presidency, his reasons for planning to return to the United States, his disillusionment after the series of murders of black civil rights activists in the 1960s and 1970s, and the role of love and sexuality in his literary writings. A special emphasis lies on the discussion of possible parallels between Nazi Germany and U.S. racism, with Baldwin most prominently likening the whole city of New York to a concentration camp. Due to copyright reasons, this reprint is based on an English translation of the edited version published in German. A one-hour tape recording of the original English conversation between Raddatz and Baldwin is accessible at the German literary archive in Marbach.
\end{abstract}

Keywords: James Baldwin, Fritz Raddatz, unpublished interview, Germany, African-American literature, Die Zeit (German weekly newspaper)

Imagine a day in early 1978. Imagine a beautiful old villa in a medieval French town, a villa "situated offshore with a marvelous rose garden and surrounded by threehundred orange trees flaunting with their golden spheres." Imagine two friends walking through the garden, dining in the nearby restaurant, talking and joking and drinking. This is the atmosphere that German writer, editor, and journalist 


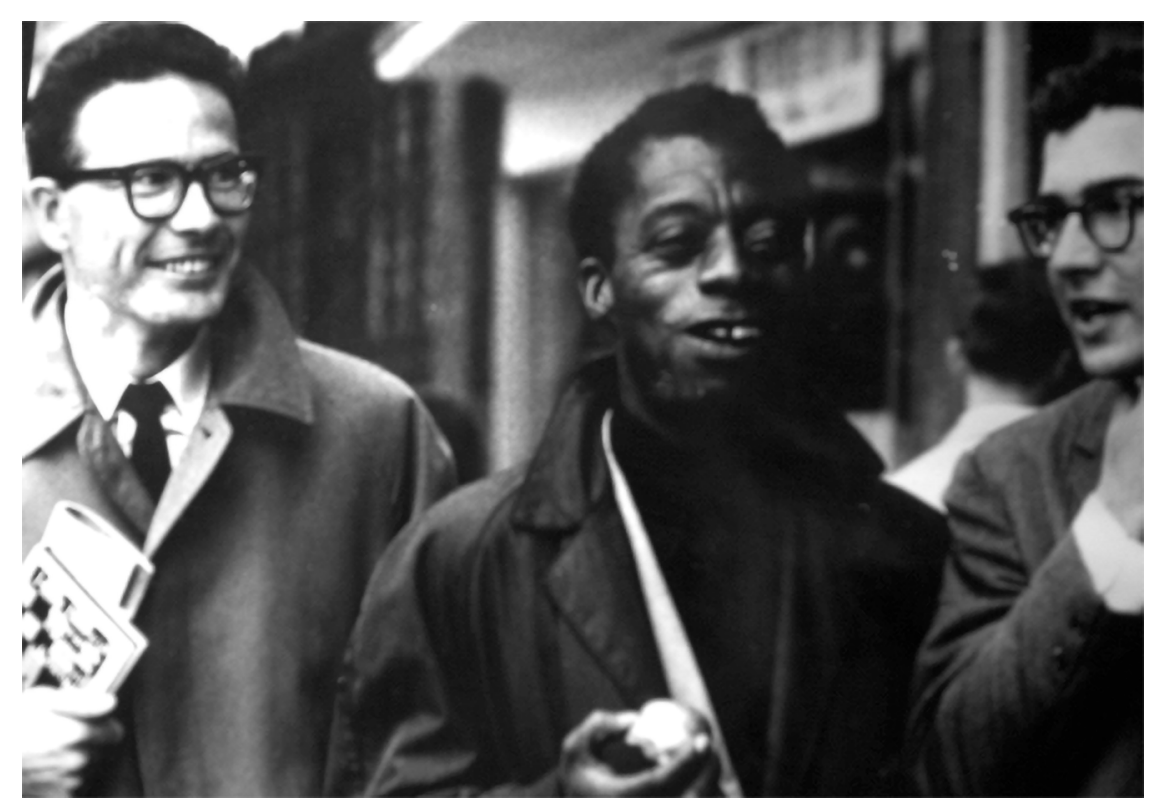

Figure 1 James Baldwin and Fritz Raddatz, 1964, (C Karin Székessy (http://karin-szekessy.de/)

Fritz Raddatz (1931-2015) wishes to evoke when-in his Parisian Diary (1988) about an extended stay in Paris that coincided with the news of Baldwin's deathhe remembers the circumstances of an interview with James Baldwin that took place in his house in St. Paul-de-Vence. More than twenty years later, in his Nizzamon amour (2010) - a book of travel writing and at the same time a declaration of love for Nice, Raddatz's adopted city-he recalls similar memories such as the scent of pine wafting from the garden of the nearby Fondation Maeght with its Giacometti sculptures. In this context, however, highlighting the beautiful and romantic surroundings serves a particular function: it constitutes a sharp contrast to Raddatz's recollection of the bitter and unsentimental topics that were part of the conversation with Baldwin. ${ }^{2}$

The interview, which left such a deep and lasting impression on Raddatz, is only one of several collaborations with the African-American writer that took place when Raddatz, who had become acquainted with Baldwin in the 1960s while working as his German editor for the left-wing publishing house Rowohlt, became head of the literary and arts sections of the German weekly newspaper Die Zeit (1977-85). ${ }^{3}$ Raddatz understood his position at Die Zeit as "a continuation of the publishing house with different means," and he saw it as his task to confront the German audience with politically subversive and intellectually challenging national and international voices. ${ }^{4}$ One of the genres that he considered most fitting to his aims was the "conversation," a form that-as a reviewer puts 
it—“is very willfully not called 'interview'. They are discursive arguments, disputatious debates, in which two conversational partners on equal footing have found a form of dispute." ${ }^{5}$ In the course of more than twenty years, Raddatz had such conversations with writers as different as Günter Grass, Nadine Gordimer, Mario Vargas Llosa, Arthur Miller, Alberto Moravia, and Toni Morrison, most of which were not only printed in Die Zeit but also published in the three-volume book edition of Raddatz's "Zeit-Gespräche."

Raddatz's conversation with Baldwin is also an example of yet another interview that-like Nazar Büyüm's 1969 interview with the African-American writer-sees its first English publication in the James Baldwin Review. However, unlike Büyüm's interview, Raddatz's conversation did not suffer the fate of being unpublished and almost forgotten for more than forty-six years. ${ }^{6}$ After Raddatz met Baldwin in St. Paul-de-Vence on 1 February 1978, he contacted him on 24 February claiming that he was "about to finish editing our interview" and asking for some recent photographs. ${ }^{7}$ The interview then appeared in Die Zeit on 3 March 1978, with a photograph of Baldwin, a photograph of Edward Kienholz's installation Five Car Stud, and a brief article on Roots in the margins of the same page. In the same year, the interview was published in two other media: in volume one of the book version of Raddatz's conversations for Die Zeit, as well as-in Italian translation-in the Italian daily newspaper La Repubblica. ${ }^{8}$

While the interview was never published in English, the original English conversation on which it was based is still accessible. The German literary archive in Marbach holds a 62-minute tape of Baldwin and Raddatz talking to each other, which served as raw material for the edited interview. ${ }^{9}$ However, it should be noted that the differences between the conversation on the tape and the published interview are quite striking. Most notably, they differ in their length, with the tape version consisting of about three times as many words as the published version. This, of course, results in numerous shortenings. On the one hand, several topicsthe experience of being poisoned by one's own country, the conception of writing as a matter of being able to make a confession, Baldwin's touching recollection of a "gingerbread colored boy" asking him a "real" question — can solely be found on the tape, while other matters appear in the published version only in considerably condensed form. On the other hand, the published version introduces some ideas that do not correlate to any passage on the tape at all. For example, neither the example of Samuel Goldstein in 1936's Berlin nor the passage about Jakov Lind nor the LeRoi Jones quote can be found on the tape. However, Raddatz's documented recollections of his visit at St. Paul-de-Vence suggest a possible explanation for this. They indicate that he spent much more time with Baldwin than the one hour recorded. Thus, it is possible that the unrecorded topics were addressed when no recorder was present-perhaps during lunch (and/or dinner) at Colombe d'Or, during their walks among the orange trees, or while admiring the Giacomettis at Fondation Maeght.

As the Raddatz estate did not agree to the publication of a version based on the tape, the conversation here represents my English translation of the edited German 
conversation with Baldwin published in Die Zeit and in the book Zeit-Gespräche. I am grateful to Joachim Kersten (Raddatz Estate), Eileen Ahearn (Baldwin Estate), and the staff of the Deutsches Literaturarchiv Marbach for agreeing to and supporting this endeavor. The photograph that accompanies the reprint shows Baldwin and Raddatz in 1964. It was taken by the German photographer Karin Székessy, who told me that she photographed a whole series of Baldwin and his sister in 1963. ${ }^{10}$ I originally found the photograph in a volume of images accompanying the publication of Raddatz's diaries, which also includes a second photograph showing Baldwin, Raddatz, and Raddatz's then-lover Eckfried Herbst at dinner. ${ }^{11}$ Unfortunately, I could not identify the photographer of the second image. Thank you to Karin Székessy for agreeing to the reprint of her photograph and for providing me with a printable version of it.

FR: President Carter wouldn't be President Carter without the black votes. If there were elections tomorrow, would you vote for him again?

JB: I didn't vote for him in the first place. I would never vote for him.

FR: Why not?

JB: Jimmy Carter is a person of integrity, for sure, but he's also a useless politician. I find it impossible to believe a word he says-as I found it always impossible to have trust in any white politician, in any American president. None of them was my president.

FR: You're definitely going back to America-that's a "historic" decision after spending twenty-five years mostly in European exile. Why?

JB: As unbelievable as it may sound, I can't exactly say why. I smell water like a horse smells water-I sense something, I feel something. Until now, this instinct never failed me. You know, when I wrote The Fire Next Time people were dismissing it as a form of black prophecy. A year later, America's cities were burning.

FR: But now there are no cities burning. There is no militant or even revolutionary black movement in the U.S. There's hardly one thought-provoking voice, not even that of James Baldwin.

JB: There's a lot to say on that subject. The ugliest part first: because they were all murdered. Ask me about the Black Panthers, about Black Power. Ask me, and I'll tell it how it is. They were killed, they were slain, like rats on the street, in their houses, in their beds.

FR: But Jimmy ... 
JB: No, don't interrupt me. This story is far too merciless for that-and I've to tell you about it if we're having this conversation. Since they could buy us as slaves on the auction block, the whites in this country merely used us and threw us away, as they do today with their cars and their Kleenex tissues. We were and we are merchandise. Race struggle is class struggle. Every unemployment rate proves that, even today in 1978. They humiliated us. They destroyed our identity, and when we began to discover a new one...

FR: ... Black is beautiful ...

JB: Call it as you wish. But there was a time when black school children, when you showed them photographs and asked them how and who they wanted to be in the future, finally began to abandon the habit of automatically pointing to the image of a white person. This was the time when I asked: "Why of all things should I want to become like a Kennedy or even like a Nixon? What do they have to do with me? I would rather kill myself with the help of a few bottles of Scotch, twenty-seven sleeping pills, or a razor than wish to become one of them!" Then, in reaction to that, the whites began to use their weapons. They no longer destroyed merely our souls, our sense of self-respect; they killed us physically.

FR: But Jimmy, there are no concentration camps in America.

JB: You especially as an anti-Nazi shouldn't talk like that. The whole city of New York is a concentration camp, a ghetto. There is none of us that wasn't in danger, none of us that doesn't have one slain in his family, and there is almost no family without at least one person who became a criminal precisely because of that. I myself know how my fear made me feel that tingling lust to kill often enough. The glorification of massacre is even part of American folklore. It's stylized to a noble and heroic legend, and thus accepted and imitated.

FR: As little as history repeats itself, as little does it stand still. You are deducing from the past: to you, the individual James Baldwin, nothing is happening today. You have overcome the story of blood and terror.

JB: That's a noteworthy number of mistakes in one sentence, Fritz. What happened to me-me-a thousand years ago is happening to me now. Two endings of the same story: My name is Baldwin, I bear the name of a white man; do I have to explain to you of all people what that means? This man was once my owner! The other ending: One of my earliest memories is the day when I-I was six-was almost beaten to death by two white police officers. Who was speaking then, myself or my history? The polyps [sic] or their history? How can I view history as something of the past when two grown men are treating a child in such a criminal way for the sole reason that the child's skin-color is black, a child who doesn't even know 
what it means to be black? I've known it since that day. This country of America, my compatriots-they are my murderers.

FR: Are you returning to your murderers voluntarily? Are you Mr Samuel Goldstein who can't decide to leave his fur store in Berlin in 1936?

JB: I'm going to tell you something: It's much, much more complex. I don't want to minimize the agony that the Jews had to suffer from the Germans in your country. I only want to quote an answer, a phrase that I once used in a similar conversation with your Jewish colleague Jakov Lind. He was telling me about his illegal journey through Nazi Germany by train. ${ }^{12}$ And I said to him: I couldn't have done it. Do you understand? A blond wig would not have helped me. That is the first part, the individual one. You have to add that, when you say that I'm not in danger today, that you can't make any generalizations from the situation of a relatively wellknown artist. It doesn't depend on me as an individual; I can only be a membrane, a voice. And even a James Baldwin, a Harry Belafonte, a Sammy Davis Jr., even they are affected. Do you remember how they let Billie Holiday die, exactly those same whites who applauded her earlier, even when she sang "Strange Fruit"? You sure know the millionaire Sammy Davis's terrible phrase: "Being a star has made it possible for me to get insulted in places where the average Negro could never hope to go and get insulted. Maybe by 1999 I'll even be able to rent an apartment in one of those buildings where they throw parties in my honor."13

FR: I know his book, I know your books-I know, I know that you're absolutely right. What I wanted to get at: All your works are pervaded, are sustained by a vision, a sermon for love, for forgiveness. I don't sense any vengefulness, any violence. I find the prophecy of love at times even going too far, it seems sentimental. Sentimentality is the opposite of emotion. It is usually the disclosure of a fracture. How do you reconcile your almost hateful verdict about your country with this kind of sermon?

JB: This, I'm sorry, again asks for an answer with multiple twists. No, I'm neither a sentimentalist nor a romantic. I'm not at home in America, and I will never be, which means that I will never be at home, not anywhere in the world. But, as strange as it may sound: I love this country. When I came to France as a young man, I woke up in the nights in agony, screaming from terrible dreams-it must have been the horror of being uprooted one more time. It feels like being born again. Or like drowning, like disappearing into nothingness. I don't belong to Africa; Africa is utterly foreign to me. I don't belong to Chartres; even if I touch this culture, I touch it the way a sculpture by Giacometti does. But it was made by him. I'm the despised bastard of the West. And as long as people-people, that is: all blacks, all whites-don't accept that we have the same right to love, as long as they continue to denounce us and are not willing to see the mountain of rubble, the pile of corpses, as long as that is the case, all of us will be murdered, in different ways: burned, 
hanged, drowned, castrated-and many are already dead when they're still alive. You're right: I am a prophet and a preacher.

FR: Is this contradiction the strange contradiction that characterizes many of your books? On the one hand, there is this endless chain of growing unhappinessblack self-hatred, the experience of being merchandise, of being a sexual object, and then the impossibility of continuing to love; for example, your character Rufus in Another Country, who dies from a kind of re-injection of the white mania, who becomes a kind of anti-white racist and who-instead of experiencing happiness from the love of a white woman-feels corroded by it. A "criminal out of lost identity." ${ }^{14}$ On the other hand-if I may stay with the example of this character-when Rufus is dead, his white friend Vivaldo thinks: "Could I have saved him if I had reached out my hand a tiny little bit back then and held him?"15

JB: Hope and its permanent disappointment, that is no contradiction-except if you wish to call life a permanent contradiction.

FR: But almost all your characters drift apart from each other even while they are still in love, their embraces are rather entanglements, reaching for a clinch that does not lead to closeness, but only to an ephemeral avoidance of the blows.

JB: This is what the white American civilization did with, did to humans. You once told me the story of a white German military officer who entered Picasso's Parisian studio in 1942, saw Guernica, and asked: "Did you make this?" Picasso answered: "No, you did!" This is the answer that I must return to you. And even today, when we had lunch and I was asking about the smear campaign against the intellectuals in Germany, about Grass and Böll, you told me about "everyday fascism," about Brecht's play The Jewish Wife, whose "Aryan" husband sends her to friends in Amsterdam in midsummer 1935 "for four weeks only," and who assists her getting into her fur coat. ${ }^{16}$ This is also what I have to return to you as an answer. Do you think this comes to a halt in front of any, even the most intimate, area of life? I could write another-thousands-of one-act plays called "The White Man." When I was very young, a friend took me home to his parents. He had told them about me. They wanted to meet me. When I entered the room, their jaws dropped-he had forgotten to tell them that I'm a Negro. My fur is my skin. It's black.

FR: Does that explain why sexuality plays such an important role in your books?

JB: It doesn't play a more important role in my books than in the lives of people. I don't write sex books. There is no obscenity in my works. At least, if you accept my definition of obscenity. To me, the neutron bomb is obscene-but not a penis. To me, the phrase "I'm shooting" is obscene when it means "I'm coming" - not the word "fucking." To me, it's obscene that, to a white man, I'm a sexual organ to which - unfortunately - a human being is attached. 
FR: You're exaggerating.

JB: I'm not exaggerating at all. By chance, there is a book by the playwright LeRoi Jones lying on the table. May I read a passage to you? "But the mutilation of the sex organs occurs again and again during lynchings. It is not enough that the black man has been socially demanned; the actual rite must go on too. And the act of cutting off a man's sex organs and stuffing them in his mouth should be analyzed as closely and deeply as possible. By removing the black man's organs, his manness, the white man removes the threat of the black man asserting that manness, by taking the white man's most prized possession. Trying to strangle a man with his own sex organs, his own manhood: that is what white America has always tried to do to the black man-make him swallow his hatred." ${ }^{7}$ Am I still exaggerating?

FR: How do you want to write with this bitterness? You're currently working on a novel-can you write a book with such bile, with hatred?

JB: It's neither bitterness nor hatred, especially not a personal one. The largest part of my life is already lying behind me, and I could grow old as a kind of "elder statesman" here on the Côte d'Azur. But it's a kind of schizophrenia when I don't want to lose hope, when I want to be able, at least, to give hope to young people. When I once had a similar conversation with Margaret Mead, she used an image that I memorized for its horrible intensity: When a snake with two heads divides itself above or below its stomach, then it knows if it is one individual or not. If it has two stomachs, one head will try to eat up the other. I'm a snake with two heads, but one stomach. I'm an American Negro writer-which means that I live a hope despite my knowing better. If I stayed away, I'd really soon stop writing. You called me a preacher-you may call me a missionary. A black missionary for the white heathens in America. What's happening in this country is unacceptable for me. And if it perishes in the flames-this country is bad enough. I'll disappear with it, but I won't accept it.

\section{Notes}

1 Fritz Raddatz, “Notizen eines Flaneurs. Pariser Tagebuch," Die Zeit, 26 February 1988, www.zeit.de/1988/09/notizen-eines-flaneurs (accessed 17 November 2017). The translation is my own.

2 Fritz Raddatz, Nizza - mon amour (Zürich, Arche, 2010).

3 A detailed analysis of the decades-long association between Baldwin and Raddatz can be found in Gianna Zocco, "Disturing the Peace of 'Two Not So Very Different' Countries: James Baldwin and Fritz Raddatz," James Baldwin Review, 3 (2017), pp. 89-109.

4 Fritz Raddatz, Unruhestifter. Erinnerungen (Berlin, LIST, 2005), p. 369. The translation is my own.

5 “Von Zeit Mitarbeitern," Die Zeit, 16 April 1982, www.zeit.de/1982/16/von-zeitmitarbeitern (accessed 17 November 2017). The translation is my own. 
6 See Rich Blint and Nazar Büyüm, "I'm Trying to be as Honest as I Can': An Interview with James Baldwin (1969)," James Baldwin Review, 1 (2015), pp. 112-29.

7 A telegram sent to Baldwin on 27 January 1978 probably refers to their scheduled meeting for the interview. It states: "Arriving nice wednesday february first at 13.10 hours. Will call you from airport and suggest meeting for lunch at colombe d'or." Deutsches Literaturarchiv Marbach (hereafter DLA), A:Raddatz, telegram by Fritz Raddatz to James Baldwin, 27 January 1978. The same date is also listed on the tape in Marbach. The information that Raddatz is about to complete editing the interview can be found in a second telegram from 24 February 1978. See DLA, A:Raddatz, telegram by Fritz Raddatz to James Baldwin, 24 February 1978.

8 See Fritz Raddatz, "'Ich lebe eine Hoffnung wider besseres Wissen.' Ein ZEIT-Gespräch mit James Baldwin,” Die Zeit, 3 March 1978, http://pdf.zeit.de/1978/10/ich-lebe-einehoffnung-wider-besseres-wissen.pdf (accessed 17 November 2017); Fritz Raddatz, "Ich lebe eine Hoffnung wider besseres Wissen.' Gespräch mit James Baldwin," in Fritz Raddatz, ZEIT-Gespräche (Frankfurt/Main, Suhrkamp, 1978), pp. 113-22; Fritz Raddatz, "Ecco i miei assassini," La Repubblica, 21 March 1978.

9 See DLA, TTS:CXN Raddatz, Fritz J.3, tape of Raddatz's interview with James Baldwin, 1 February 1978.

10 Email to the author, 8 February 2017.

11 See Fritz Raddatz, Die Tagebücher in Bildern (Reinbek bei Hamburg, Rowohlt, 2011), pp. 46-7.

12 The Austro-British writer Jakov Lind fled from Vienna to the Netherlands after his father had been arrested by the Gestapo. After the German invasion of the Netherlands he managed to obtain a false identity and spent the last years of the Second World War in Germany.

13 See Sammy Davis Jr., and Jane and Burt Boyar, Yes I Can: The Story of Sammy Davis Jr. (New York, Farrar, Straus \& Giroux, 1965), p. 381.

14 This is Raddatz's phrasing in Fritz Raddatz, "Schwarz ist die Farbe der EinsamkeitSkizze zu einem Porträt James Baldwins," Frankfurter Hefte, 20:1 (1965), p. 45.

15 In all likelihood, Raddatz is referring to the passage in Another Country in which Vivaldo is described as thinking: "What would have happened if I'd taken him in my arms, if I'd held him, if I hadn't been—afraid." James Baldwin, Another Country (London, Penguin, 2001), p. 336.

16 "The Jewish Wife" is one of twenty-four playlets that make up Bertolt Brecht's play Fear and Misery of the Third Reich (1938).

17 LeRoi Jones [Amiri Baraka], “American Sexual Reference: Black Male," in LeRoi Jones [Amiri Baraka], Home: Social Essays (New York, Akashic Books, 2009), p. 259.

\section{Works Cited}

Baldwin, James, Another Country (London, Penguin, 2001).

Blint, Rich, and Nazar Büyüm, “I'm Trying to be as Honest as I Can': An Interview with James Baldwin (1969)," James Baldwin Review, 1 (2015), pp. 112-29.

Davis, Sammy, Jr., and Jane and Burt Boyar, Yes I Can: The Story of Sammy Davis Jr. (New York, Farrar, Straus \& Giroux, 1965).

Jones, LeRoi [Amiri Baraka], "American Sexual Reference: Black Male," in LeRoi Jones [Amiri Baraka], Home: Social Essays (New York, Akashic Books, 2009), pp. 243-62.

Raddatz, Fritz, "Ecco i miei assassini," La Repubblica, 21 March 1978. 
“'Ich lebe eine Hoffnung wider besseres Wissen. Ein ZEIT-Gespräch mit James Baldwin,” Die Zeit, 3 March 1978, http://pdf.zeit.de/1978/10/ich-lebe-eine-hoffnungwider-besseres-wissen.pdf (accessed 17 November 2017).

"'Ich lebe eine Hoffnung wider besseres Wissen.' Gespräch mit James Baldwin," in

Fritz Raddatz, ZEIT-Gespräche (Frankfurt/Main, Suhrkamp, 1978), pp. 113-22. Nizza - mon amour (Zürich, Arche, 2010).

"Notizen eines Flaneurs. Pariser Tagebuch," Die Zeit, 26 February 1988, www.zeit.de/1988/09/notizen-eines-flaneurs (accessed 17 November 2017).

"Schwarz ist die Farbe der Einsamkeit-Skizze zu einem Porträt James Baldwins,"

Frankfurter Hefte, 20:1 (1965), pp. 44-52.

Die Tagebücher in Bildern (Reinbek bei Hamburg, Rowohlt, 2011).

Unruhestifter. Erinnerungen (Berlin, LIST, 2005).

"Von Zeit Mitarbeitern," Die Zeit, 16 April 1982, www.zeit.de/1982/16/von-zeit-mitarbeitern (accessed 17 November 2017).

Zocco, Gianna, "Disturing the Peace of 'Two Not So Very Different' Countries: James Baldwin and Fritz Raddatz," James Baldwin Review, 3 (2017), pp. 89-109.

\section{Contributor's Biography}

Gianna Zocco is a University Assistant in the Department of Comparative Literature at the University of Vienna. Her work focuses on American (especially African-American) and German literature, with a particular interest in cultural concepts of space, imagology, intertextuality, reception studies, postcolonial studies, and theories of cosmopolitan memory in literature. She is currently working on a book project on the images and functions of the German-speaking region and its history in African-American literature. 
